\title{
Mission Challenges in the New Millenium
}

\author{
Fransiskus Irwan Widjaja, ${ }^{1}$ Joni Manumpak Parulian Gultom \\ Theology Study Program, Real Theological Seminary Batam ${ }^{1,2}$ \\ fransiskus.fiw@gmail.com
}

\begin{abstract}
This paper is an analysis of various collective resources to consider new challenges in the world of mission. Throughout the third millennium, Christianity was faced with historically enormous goals and opportunities. The missionary activity is more than two centuries old. It appears that God moved His people in the event of a great wave of spreading the gospel to various parts of the world. This missionary movement has made it possible for the gospel to be accepted and heard by thousands and even millions of people representing various tribes, ethnicities and cultures. The Bible is translated into hundreds of languages and dialects. according to the phenomenon observed above, today the Church and Christianity are challenged to carry out the Mission in a far greater opportunity. Seeing the fastpaced changes in this era actually raises a hope of the birth of a new mission movement in the challenges of the new millennium. This paper aims to provide a missiological overview of the possibility of a new missionary movement emerging. Keywords: Mission, Challenges, Milenium Era
\end{abstract}

\section{INTRODUCTION}

As we approach the beginning of the third millennium, the world seems to be changing quickly. An increasing number of thinkers are declaring this a "postmodern world".

For the greatest challenge facing Christians mission today as we enter the third millennium is Christian faith is relevant to all questions and all problems. And what the facts of facing mission today?

\section{Facts}

The Gordon Cornwell published the research in $2013^{1}$, the prediction of the growth of the Christianity. The data shown the last 50 years (1970-2020) the church or the believers increase only $0.1 \%$. The growth of the mission today is not focusing on urban but also rural, even on the unreached people group. The mission almost occur in all corners of the earth, But the result is not progress. Mission is failed? What is the challenge of Mission in nowdays or in this new Millenium?

${ }^{1}$ Christianity in Its Global Context, 1970-2020. Centre for the Study of Global Christianity, Gordon Cornwell, Theological Seminary, June 2013 
Table Religious Adherents 1970-2020²
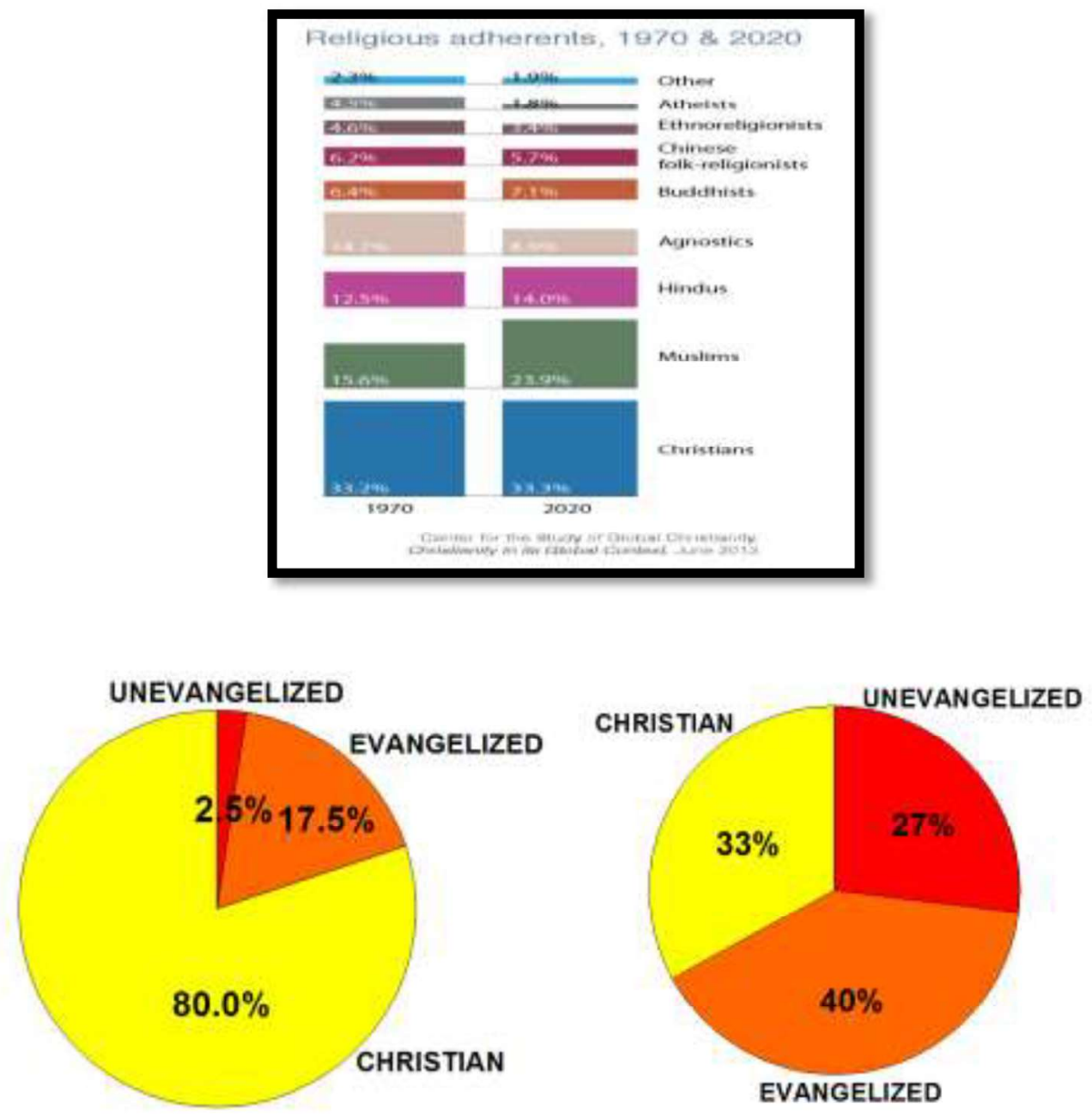

When we look at the Table, it means no growth during the last 50 years of Christianity. There are the factors that involved in the stagnancy of the grwoth of the Christianity. THE MISSIONS WE ARE DOING IN THE CHRISTIANS WORLD. It means no mission at all?

\section{METHOD}

In this study, the authors collected data from various sources, which were analyzed and developed as part of a descriptive analysis interpreting the data. Including interpreting the verses of God's words related to the topic of Mission. This research includes literature research. Writing that analyzes the data that

2 ibid 
occurs, in accordance with the topic being written. The main data source is from social media info; John Hopkin University's official website, Joshua project, data from Indonesian people Network, unreached people research network, data from Gordon Cornwel University, Bilangan research center. The source of the data source is the main source and is the direct research published to help the church complete the Great commission. Data from researchers in their respective fields are linked to phenomena that occur, making this topic a discussion that results in conclusions and explanations. The analysis is expected to help remember practitioners, pastors and evangelists in preaching the gospel throughout the world.

\section{RESULTS AND DISCUSSION \\ The Mission Challenging \\ External challenges}

The existence of a postmodern era in a new era that brings new morality to personal standards, such as LGBT, homosexuals and polygamy. This personal standard has become a new religion replacing Christianity. Issues of religious radicalism, such as propaganda, terrorism and various movements carried out by a group of people who have the heart to act extreme. This seems to corner every church. Not only that, this also raises the symptoms of intolerance and religious fanaticism and excessive exclusivism in religious social relations in society. The rise of various heresies and heresies that have cults, such as the Gnostics, Mormonism, Christian Science, Jehovah's Witnesses and so on. This is contrary to Jesus' warning to His disciples (Matthew 24: 3-14; 1 Timothy 1: 3; Romans 16:17). Persecution of Christians is regarded as antisocial and causes of riots. As is told about the sponsorship of Stephen (Christian martyrs) and a number of Jerusalem churches (Acts 7: 54-8: 3). Humans who are more intelligent and alive feel as if they no longer need God. This is contrary to God's will (Romans 12:16 "but direct yourself to simple things. Do not consider yourself clever!").

\section{The challenge of individualism}

Millennials often depend on gadget tools, so the gadget has become a tool for the new model 'idols'. Seen from each congregation rarely carry printed bible because the Bible has become a digital bible on HP or Ipad. Even more sadly during the service, they still play social media, such as Facebook, Instagram, and so on. This is the beginning of the hedonism and materialism that Christians often do (James 4: 1-5: 6; 1 John 2: 15-17). In essence, we must present and model ways of thinking about the challenges of the present church and how to overcome them by clarifying their culture that the Christian faith (Romans 15: 6; 1 John 5: 4-5) must be relevant to all questions about the challenge 


\section{Internal Challenges}

Church divisions due to money problems, different interpretations, differences in group interests and so on (1 Corinthians 3: 3). Increase of wealth, materialism, Increase of Ego, self image and Wrong image of success

Gandi $^{3}$, mentioned seven deadly sins that may happened in the church today as writer observed during the last 21 years as served as fulltime ministry and educator. Seven deadly sins according to Gandhi's:

- rich without working

- Pleasure without conscience

- Knowledge without Character

- Business without morality

- Science without humanity values

- Religion without sacrifice

- Politics without principles

Flash back

\section{Mission in Jesus Times}

The mission that Jesus did was the Mission of the Kingdom of God ${ }^{4}$. Jesus' mission is the New Testament mission, model. He formed the community to live under God's rule. In Matthew 4: 13-17 the writer reports that Jesus began His call to convert the unbelievers in Galilee, to fulfill the prophecies in Isaiah 28:23 and 9: 2 , that "those who walk in great darkness" above it was called the territory of the Gentiles, "had seen the great Light" of Jesus (Matthew 4: 15-16).

Matthew 8: 5-13 describes a heathen officer, who had come to believe in Jesus, about him Jesus said: "I have not found this great faith, no, not in Israel" (verse 10) and added, that many people from the far end of the earth will party with the ancestors in Heaven, while many Jews ("children of the Kingdom") will be cast out (vv. 12-13).

In Matthew 15: 21-28, Jesus was in the Gentile territory again and met a Canaanite woman who believed, who was willing to be satisfied with the crumbs of the Israelites and the Messiah. In the parable of the workers in the vineyard (Mt 20: 1-16), the Jews seem to be the first who became the latter and the other nations were the last to be the former 


\section{Jesus made disciples}

Starting His ministry, Jesus began by choosing His disciples (Matt. 4: 1822; Mark 1: 16-20; Luke 5: 1-11). Disciple and giving example are Jesus' style of mission. He taught, trained and prepared His disciples for a great work. In Matthew 4: 19 Jesus said to His disciples, "Come, follow me, and I will make you fishers of men." Jesus' consensus was to prepare the disciples to become "fishers of men", namely to win souls for His Kingdom.

\section{Jesus sent disciples}

The mission in John, the sending of disciples into the world by Jesus, is understood as the continuation of His mission from His Father and the sending of the Holy Spirit by the Father and Jesus (John 14:26, 15:26, Luke 24:49). In John 20:21, Jesus said: "Just as the Father sent me, I sent you". A clear example is when Jesus and Nicodemus met, the basic model One on one. Jesus and the Samaritan woman, He approached others, He avoided judgment, without arrogance - facts and truth in love. He met him where he was - as he was

\section{Jesus Focuses Cross-ethnic}

As the explanation above shows that Jesus loved souls not based on the ethnic background but Jesus loved any souls and wherever he came from. Jesus loves all nations (etne). In the book of John, Jesus also reaches Non-Jews. John shows Jesus' long conversation with the Samaritan woman. This ends with the recognition of the entire city of Samaria, "that this is indeed Christ, the Savior of the world" (4:42). "True devotees," must worship Him in "spirit and truth," so as to make it possible for nations who live far from Jerusalem to now worship God as well as Jews. John stressed strongly that Jesus was not only the Savior of the Jews, but for all people, and to preach the gospel to all nations. (John 17: 18-23)

Just as you sent me into the world, so I sent them into the world; and I sanctify myself for them, that they may also be sanctified in the truth. And not for them alone I pray, but also for those who believe in me by their preaching; so that they will all be one, just as you, Father, are in me and I am in you, that they too may be in us, so that the world may believe that you sent me. And I have given them glory, you give me, that they may become one, just as we are one: I in them and you in me that they may be completely one so that the world will know that you sent me and that you love them, just as you love me. (John 17: 18-23)

\section{Jesus Will Take Risks}

Jesus demonstrated that $\mathrm{He}$ was willing to risk being misunderstood for the urgent need in the well with the Samaritan woman, John 4: 1-38 said, 
"My food," said Jesus, "is to do the will of Him who sent Me and finished His work. Did not you say: Four months will come when the harvest season comes? But I tell you: Look around you and look at the fields that have turned yellow and are ripe for harvested (verses 34-35)

Like a Samaritan woman, people are willing to listen to the Good

News but there is a shortage of workers, therefore every believer must fulfill his mind like Jesus or many people will perish and go to hell. The time is about to run out, 2 Peter 3: 9 says,

God is not negligent in keeping His promises, even though there are people who regard them as negligence, but $\mathrm{He}$ is patient with you because He wants that no one perishes, but that all will turn and repent.

\section{The focus of Jesus Preaching the Kingdom of God}

The center of Jesus' preaching was about the kingdom of heaven that was near (Matt. 4:17) and therefore the listeners should repent. There is a gradual development in Matthew.

First of all, the news was brought specifically to all the lost sheep of the people of Israel (Mt 10: 5-7). This was again revealed by Jesus in Matt. 15:24 "I was sent only to the lost sheep of the people of Israel"

However, Jesus is also not bound by national, customary and religious boundaries.

o Jesus came to save the tax collector and sinners (Mt 9:9-13).

o Jesus also paid attention to the Samaritans (Luke 10; 17: 11-19; John 4).

o Jesus also traveled abroad, meaning to the territories of unbelievers (Gentiles), namely to Tire (Mk 7:24) and the birth of Caesarea Philippi (Mk 8:27)

Jesus' statement about the coming of the nations in the kingdom of heaven after meeting with Capernaum officers who came from the Gentiles. Matthew 8: 11-12 "I tell you, many will come from East and West and sit down to eat with Abraham, Isaac, and Jacob in the kingdom of heaven, while the sons of the Kingdom will be cast into the darkest darkness, that's where there will be lamentation and gnashing of teeth. "

\section{Indonesian as study case}

Bonus Demography: Demographic transition is very beneficial when the productive age population (15-64 years) experiences the largest number compared to the proportion of the non-productive age population. Surya ${ }^{5}$ Candra's workforce

${ }^{5}$ Surya Chandra, member of the House of Representatives Commission IX, in a seminar on population problems in Indonesia at the Faculty of Medicine, University of Indonesia was copied from Rosari Andhini's notes. Population Lecture Notes Material Week 15: Population Issues. Surabaya. 2017 
age (15-64 years) in 2020-2030 will reach 70 percent, while 30 percent are nonproductive people (under 15 years and over 65 years). When viewed from the amount, the productive age population reaches around 180 million, while the nonproductive population is only 60 million.

\section{CONSLUSION}

Studies of religions view syncretism as a fusion phenomenon of various religious teachings and cults. Syncretism is considered a tendency that is not realized but is often confirmed by the interests of a broader interest. As long as humans are still there and the age continues to develop syncretism will certainly exist. Even though the tendency is often not realized, in practice it is often confirmed as a new teaching and culture. In this situation religious ideas are adjusted according to the religious principles of other religions. One of the syncretic choices is to take a clear line between culture and the gospel. But as a result there has been a development of multiple systems.

Syncretism is debated, especially in the Pentecostal-Charismatic school, must be responded with a cold head. Taking a wise attitude in understanding other religions needs to be taken early. Syncretism is arguably the joint decision-making process in overcoming various problems including those related to phenomena and theology.

In response to the phenomenological problem of Synchronism, the church must be wise. The more so if it is associated with methods and strategies and mission. The church should be open and not easy to be negative about all elements of change that are relevant and do not contain elements that are contradictory to the biblical foundation. But the church cannot accept each teaching as long as it is tested and analyzed carefully, but is more required to be sensitive, positive, selective and creative. Positive selectively and creatively the church can start, use and make use of what is there. And it negates the view that it harms or denies the Christian faith, especially those related to the gospel.

With the phrase Let you be rooted in Him and be built on Him, let you increase firmly in the faith that has been taught to you, and let your heart overflow with gratitude (Colossians 2: 7). The Apostle Paul meant that: The Church of God is like a plant seed that is spread to grow and bear fruit in its own place where Christ is already there. Christianity must give independence in a responsible manner to the people in the new environment to understand, pervade, appreciate and express (express) their universal and transcendent faith in Christ according to 
their personality, culture and environment. This is legitimate and indeed has happened throughout the course of the history of Christianity.

\section{BIBLIOGRAPHY}

Budi, Kurniasih. "Sambut Bonus Demografi, Indonesia Dorong Negara G-20 Kerja Sama," n.d. https://money.kompas.com/read/2019/06/24/205905526/sambutbonus-demografi-indonesia-dorong-negara-g-20-kerja-sama?page=all.

Munir. Pembelajaran Jarak Jauh Berbasis Teknologi Informasi Dan Komunikasi. Bandung: Alfabeta, 2009.

Tanwey, Gerson Ratumanan. Konstruktivisme Dan Implikasinya Dalam Belajar Dan Pembelajaran. Ambon: FKIP Unpatti, 2002.

"HIPMI Paparkan Program Hadapi Bonus Demografi Ke Milenial," n.d. https://news.detik.com/berita/d-4823020. 